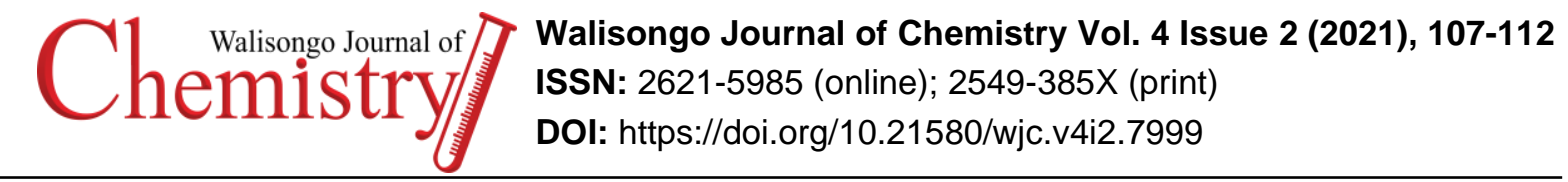

\section{Cytotoxic Activity of Ethanol Extract in Namnam Leaves (cynometra cauliflora 1.) to Hela Cell}

\author{
Syarah Anliza*, Nurmeily Rachmawati \\ Medical Laboratory Technology, Poltekkes Kemenkes Banten \\ Jalan Dr. Sitanala, Kota Tangerang, Indonesia, 15121 \\ *E-mail: syarah125@gmail.com
}

Received: 5 April 2021; Accepted: 31 July 2021; Published: 15 December 2021

\begin{abstract}
Cervical cancer is one of the most prominent death cases after breast cancer for a woman in Indonesia. Several treatments can be conducted to cure cancer such as chemotherapy, radiotherapy, tumor surgery, and others. In addition, people can consume some medicines or natural substances that can suppress cancer growth. The natural substances contain active compounds that have the potential as anticancer. One of the natural substances used in this research is the Namnam leaves which grow in Southeast Asia. The purpose of this research was to determine the potential compounds in Namnam leaves extract by cytotoxic activity testing by using HeLa cells. The active compound in the Namnam leaves extract was obtained by using the maceration method with ethanol for $3 \times 24$ hours. The extract was then tested by BSLT method and proliferation by using HeLa cancer cells (ATCC CCL-2). The toxicity results showed that LC50 value was $125,89 \mu \mathrm{g} / \mathrm{mL}$. This result indicated that the extract belongs to the moderate toxic category and has potential as an anticancer agent. Proliferation test in inhibiting of HeLa cancer cells used Microculture Tetrazolium Technique (MTT) method. The result showed that the extract with a concentration of $25 \mu \mathrm{g} / \mathrm{mL}$ could inhibit the proliferation of HeLa cancer cells by 57,51\%.
\end{abstract}

Keywords: Cytotoxic activity; ethanol extract of Namnam leaves; HeLa cell

\section{Introduction}

Cancer is a noninfectious disease caused by free radicals that are concerned in the world including Indonesia. Cancer or tumor prevalence had an increasing number around 0.4 per-mille according to doctor diagnoses in Indonesia. This data showed in Basic Health Research (Riskesdas) that conducted by the Ministry of Health in 2018 (Badan Penelitian dan Pengembangan Kesehatan, 2018). The rate of cancer disease in Indonesia had $8^{\text {th }}$ level in Southeast Asia and $23^{\text {rd }}$ level in Asia by 136.2/100,000 population. The highest occurrence for breast cancer was 42.1 per 100,000 population women following by cervical cancer 23.4 per 100,000 with a mortality rate of 13.9 per 100,000 population (Kemenkes, 2019). Several treatments were conducted to cure cancer such as chemotherapy, surgery, and radiotherapy. Chemotherapy is one of the treatments that used anticancer drugs to inhibit cancer cells growth. This treatment is not as effective as others because it has to design anticancer compounds that have high anticancer properties but low side effects to normal cells and hit the target of the cell cancer accurately (Yudistira, 2017)

Many patients have side effects after doing chemotherapy such as hair loss, 
tiredness, anemia, loss of appetite, and others (Society, 2020). Therefore, they try another treatment by consuming some natural medicines. These medicines are obtained from natural substances like a plant. Medicine made from natural substances is the best solution to prevent and cure cancer because it is safer than chemotherapy (Mutiah, 2017). A natural substance that has potential as a medicine is a plant with the Cynometra genus from Fabaceae/Leguminoseae familie.

Aziz and Iqbal identified this plant about phytochemical compounds from the extract of the plant. It contains tannin, saponin, flavonoid, terpenoid, and glycoside that had potential as antioxidants, antidiabetics, and anticancer (Sumarlin et al., 2018; (Maharani, Sukandar and Hermanto, 2016). The antioxidant of Namnam leaves extract was $66,36 \mu \mathrm{g} / \mathrm{mL}$. The leaves had higher antioxidant activity than other parts of the plant. The antioxidant properties were proven to prevent cancer cells and had a lot of advantages (Mulia, Endang Zainal Hasan, and Suryani, 2016). This extract has several phytochemical compounds that can be used potentially as antidiabetics and anticancer. The purpose of this research was to determine anticancer properties by cytotoxic activity from extract Namnam leaves to HeLa cancer cells. The research was begun with identifying the toxicity of Namnam leaves extract by using ethanol. The value of toxicity was used to determine the cytotoxic activity to test the use of HeLa cancer cells by MTT assay.

\section{Research Methods}

Tools and Materials

The tools used in this experiment were rotary vacuum evaporator (Buchii B480, incubator (Memmert), and ELISA. The ingredients used in this research were ethanol (p.a Merck), shrimp, DMSO, Dulbecco's modified eagle's medium (DMEM), RPMI 1640, Fetal Bovine Serum (FBS) 5\%, Penicillin, Streptomycin, HeLa cell (ATCC CCL-2), and Namnam plant. Namnam plant can be found in Rangkasbitung, Banten Province. The plant was identified by the
Indonesian Academy of Sciences (LIPI) with the number B-994/IPH.3./KS/IV/2019. It stated that the Namnam plant is included Cynometra cauliflora L species and a family of Leguminosae/Caesalpiniaceae.

\section{Procedure}

\section{Extraction Process}

The leaves were dried, grounded, and weighed 100 grams to have a maceration process by using ethanol by ratio $1: 5$ solvent. The maceration process took $3 \times 24$ hours. This method was a modification from (Maharani, Sukandar, and Hermanto, 2016) method and procedure from BIOFARMAKA, Bogor laboratory. The extract was condensed by removing solvent and using a rotary evaporator at $45-50^{\circ} \mathrm{C}$. This extract was called crude extract (Maharani, Sukandar, and Hermanto, 2016).

\section{Toxicity Test}

According to Lestari, Kartika, and Marliana (2019), the toxicity of the extract then was tested by using BSLT method and shrimp larvae of Artemia salina. The shrimp larvae egg $(10 \mathrm{mg}$ ) was incubated in $250 \mathrm{~mL}$ seawater using a lamp and aerator for two days. Ten shrimp larvae that had been hatching were added to $1000 \mu \mathrm{L}$ seawater. Each vial contains ten shrimp larvae, seawater, and additional extract of the concentration $10 \mathrm{ppm}$; $50 \mathrm{ppm} ; 100 \mathrm{ppm}$; 500 ppm; and 1000 ppm consecutively. Each concentration replicated the test three times. For control, it used ten shrimp larvae and seawater without adding extract. The solution was observed for 24 hours to see shrimp larvae mortality. To determine shrimp larvae mortality, it can be calculated by the following formula:

$\%$ mortality $=\frac{\text { Llarvae mortality }}{\Sigma \text { total larvae }} \times 100 \%$

The value of $\mathrm{LC}_{50}$ was obtained from Probit analysis by using a regression linear curve which $\log 10$ concentration as $\mathrm{x}$-axis and Probit as y-axis (Mshelia E.H., Maigari and, Yohanna Christopher., and Ismail, 2016). 
Microculture Tetrazolium (MTT) Assay

The Primate Animal Study Center (PSSP) IPB, Bogor, has ever held proliferation test by using the procedure. HeLa cancer cells can be grown by a concentration of 5000 cells in $100 \mu \mathrm{L}$ on a growing medium. The extract was added after the cell reached confluent $50 \%$ in 24 hours. Microculture Tetrazolium Technique (MTT) assay was done after day 3 by adding MTT $(5 \mathrm{mg} / \mathrm{mL}) \quad 10 \mu \mathrm{L}$ per well then incubated for 4 hours at $37^{\circ} \mathrm{C}$. Formazan crystals were dissolved with ethanol. Absorbance was measured at wavelength $595 \mathrm{~nm}$ by ELISA reader. The absorbance was converted into inhibition percentage to determine the cytotoxic activity of the extract.

\section{Results and Discussion}

The extract of Namnam leaves used ethanol solvent by ratio 1:5 with maceration method for $3 \times 24$ hours. This solvent was categorized as a polar solvent that easily attracts polar compounds such as phenolic compounds (Manongko, Sangi, and Momuat, 2020). It's also an organic solvent that was used to dissolve an organic compound or being used as a solvent extract (Ismiyati, 2015). To determine the toxicity of the extract, the use of BSLT method had several advantages such as simplicity, rapidness, inexpensiveness, and having high degrees of repeatability (Nofita, Maria Ulfa, and Delima, 2021). This method was used to test if such compounds had potential as anticancer properties by calculating the mortality rate of shrimp larvae Artemia salina. The number of shrimp larvae mortality on each concentration was shown in table 1 . The value of $\mathrm{LC}_{50}$ was obtained from the graph by plotting probit analysis using a regression linear curve.

Table 1 shows that the extract had a toxicity value of $\mathrm{LC}_{50}$ at $125.89 \mu \mathrm{g} / \mathrm{mL}$. Meyer et al stated that extract from natural substances was classified as toxic if it had a value of $\mathrm{LC}_{50}<1000 \mu \mathrm{g} / \mathrm{mL}$, while its pure compound had a value of $\mathrm{LC}_{50}<200 \mu \mathrm{g} / \mathrm{mL}$. It means that it had potential as an anticancer. Lestari et al stated that if the value of $\mathrm{LC}_{50}>1000 \mathrm{ppm}$, its category was non-toxic substances (Nofita, Maria Ulfa, and Delima, 2021).

\begin{tabular}{ccc}
$\begin{array}{c}\text { Table 1. Lethal Concentration of } \\
\text { against } \\
\text { Concentrations }\end{array}$ & $\begin{array}{r}\text { Different } \\
\text { Extract }\end{array}$ \\
\hline \multicolumn{4}{c}{$\begin{array}{c}\text { Average } \\
\text { Concentration } \\
(\mu \mathrm{g} / \mathrm{mL})\end{array}$} & $\begin{array}{c}\text { Mortality } \\
\text { Shrimp Larve } \\
\text { Artemia salina } \\
\text { Leach }\end{array}$ & $\begin{array}{c}\mathrm{LC}_{50} \\
(\mu \mathrm{g} / \mathrm{mL})\end{array}$ \\
\hline 10 & 2 \\
50 & 2 & 125,89 \\
100 & 3 & \\
500 & 8 & \\
1000 & 9 &
\end{tabular}

There are several classifications of toxicity by $\mathrm{LC}_{50}$ values. If the value of $\mathrm{LC}_{50}$ is $500-1000 \mathrm{ppm}$, it is classified as low toxic, 100$500 \mathrm{ppm}$ as moderately toxic, and $0-100 \mathrm{ppm}$ as highly toxic. The value of $\mathrm{LC}_{50}$ of this research showed that ethanol extract of Namnam leaves was in the moderate toxic category and had the potential for anticancer substances (Mshelia E.H., Maigari and, Yohanna Christopher., and Ismail, 2016).

Cancer causes progeny from normal cells that have lost their cellular activities in controlling proliferation. It could have happened because of growth factors in the specific location that received instruction to grow and division of cells (Berridge, 2012). HeLa cell culture was adopted from a woman who suffered cervical cancer named Henrietta Lack who died in 1951 (Suraduhita, 2017). This cell is a continuous cell line that can be used as a cancer cell model and learn about the cellular transduction signal. It's also a safe cell to be used in the research and human cell in general which can be used in cell culture (Kurniawan, Chandra; Siagian, Jonathan Willy; Hutomo, 2016). The proliferation test was conducted by MTT method. This method had a principal reduction of yellow tetrazolium MTT salt by using the reductase enzyme. The succinate tetrazolium reacted into respiration cycles in mitochondria cells and formed a purple formazan crystal. This crystal was not 
dissolved into the water by adding a stopper reagent. The crystal was dissolved and measured in ELISA reader at wavelength 595 nm (Tatiana and Ria, 2020).

Based on the concentration result in the toxicity test by using BSLT method, the concentration extract that used in this MTT assay was $100 \mathrm{ppm} ; 50 \mathrm{ppm} ; 25 \mathrm{ppm} ; 12.5$ ppm; $6.25 \mathrm{ppm}$. The extract and HeLa cancer cells were combined then measured in ELISA reader. The potential anticancer agent of the extract Namnam leaves was shown in percentage inhibition data which inhibit HeLa cancer cells growth. The data was shown in table 2 and the picture below.

Table 2. Proliferation Result of Extract Namnam Leaves in HeLa Cell

\begin{tabular}{ccc}
\hline $\begin{array}{c}\text { Consentration } \\
\text { (ppm) }\end{array}$ & \% Inhibition & $\begin{array}{c}\text { IC }_{\mathbf{5 0}} \\
(\boldsymbol{\mu g} / \mathbf{m L})\end{array}$ \\
\hline 100 & 94.49 & \\
50 & 93.08 & \\
25 & 57.51 & $\sim 25$ \\
12,5 & nd & \\
6,25 & nd & \\
\hline
\end{tabular}

Table 2, it showed the value of $\mathrm{IC}_{50}$ at concentration $25 \mu \mathrm{g} / \mathrm{mL}$. This value was obtained from percent inhibition of HeLa cancer cells that could inhibit or equal to 50\% from initial concentration (Fassy et al., 2017). The picture above has shown the morphology of HeLa cancer cells after treatment with ethanol extract of Namnam leaves by various concentrations. Increasing extract concentration of Namnam leaves indicates that the HeLa cancer cell could be inhibited higher than $50 \%$. It's shown in morphology by using the colony of the cell was apart from center growth (control). It is also shown that some of HeLa cancer cells were damaged and others were still the same with control. This extract contained flavonoid and tannin compounds. Flavonoids in the extract of Namnam leaves could presume to inactivate the carcinogen, inhibit of angiogenesis process, antiproliferation, inhibit the cycle of cells, restore resistance to medicine, and combine from all the mechanism (Diba, Salni and Subandrate, 2019). Tannin compounds contained in an extract could inhibit the growth of cancer cells (Fitriana, 2019). This extract of Namnam leaves could be developed as medicine and curing of cervical cancer by doing this research results to fractionate the extract. Therefore, the pure compound obtained from the extract could assess the mechanistic target of cervical cancer or proliferation cycles to the cancer cells.

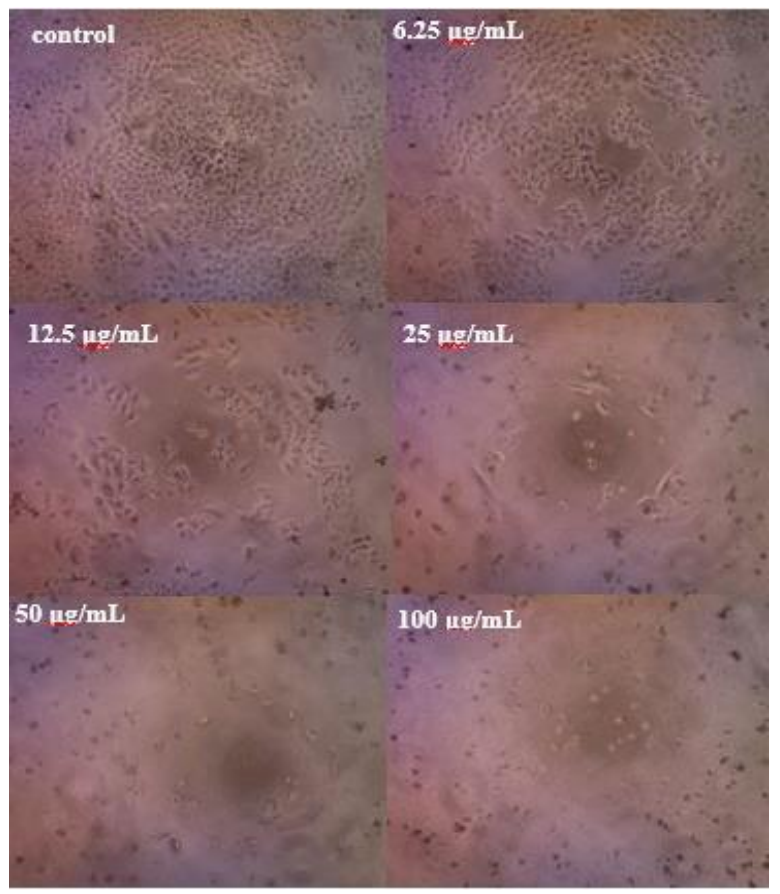

Figure 1. Morphology of HeLa cell in Ethanol Extract of Namnam Leaves

\section{Conclusions and Suggestion Conclusions}

The toxicity of ethanol extract in Namnam leaves was tested by using BSLT method. It showed that the value of $\mathrm{LC}_{50}$ was $125.89 \mu \mathrm{g} / \mathrm{mL}$ with the category as toxic and had potential as an anticancer agent. Proliferation inhibition of HeLa cancer cells by MTT method showed a value of $57.51 \%$ at the concentration of $25 \mu \mathrm{g} / \mathrm{mL}$ of extract. The extract had big potential to be developed as an anticancer agent for cervical cancer.

\section{Suggestion}

To improve the potential of Namnam leaves extract, the research is possibly conducted on other cells or by in vivo process. 


\section{Acknowledgments}

This research was funded by DIPA Poltekkes Kemenkes Banten in 2019.

\section{References}

Badan Penelitian dan Pengembangan Kesehatan (2018) 'Laporan_Nasional_Riskesdas2018_FIN AL.pdf', Badan Penelitian dan Pengembangan Kesehatan, p. 198. Available at: http://labdata.litbang.kemkes.go.id/im ages/download/laporan/RKD/2018/L aporan_Nasional_RKD2018_FINAL.pdf.

Berridge, M. J. (2012) 'Cell Signalling Biology Module 9: Cell Cycle and Proliferation', Biochemical Journal, 9, pp. 1-42. doi: 10.1042/csb0001009.

Diba, M. F., Salni and Subandrate; (2019) 'Uji Sitotoksik Ekstrak Dan Fraksi Dendrophtoe Pentandra (L) Miq Pada Sel T47D', Jurnal Kimia Sains dan Aplikasi, 22(3), pp. 73-78. Available at: https://ejournal.undip.ac.id/index.php /ksa/article/view/22075.

Fassy, F. et al. (2017) 'In Vitro Characterization of VPS34 Lipid Kinase Inhibition by Small Molecules', Methods in Enzymology, 587, pp. 447-464. doi: 10.1016/BS.MIE.2016.09.070.

Fitriana, S. D. (2019) Uji Aktivitas Antikanker Ekstrak dan Isolat Tanin Rumput banbu (Lophaterum gracile B.) yang Diembankan pada Zeolit NaX terhadap Sel Kanker Payudara T47D dengan Metode MTT. Universitas Islam Negeri Maulana Malik Ibrahim Malang. Available at: http://etheses.uinmalang.ac.id/id/eprint/15249.

Ismiyati, D. A. (2015) 'Pengaruh Konsentrasi Pelarut Pada Proses Ekstraksi Antosianin Dari Bunga Kembang Sepatu', Konversi, 4(2), pp. 9-16.

Kemenkes (2019) Hari Kesehatan Nasional 2019. Available at: https://www.kemkes.go.id/article/vie w/19020100003/hari-kanker-sedunia2019.html\#: :text=Hari\%2520Kanker $\% 2520$ Sedunia\%2520diperingati\%252 0setiap\%252tanggal\%25204\%2520Fe bruari. (Accessed: 31 January 2019).
Kurniawan, Chandra; Siagian, Jonathan Willy; Hutomo, S. (2016) 'Sitotoksisitas Ekstrak Etanolik Curcuma Longa Pada Sel Hela, Studi In Vitro', Berkala Ilmiah Kedokteran Duta Wacana, 1(3), pp. 165172.

Lestari, D., Kartika, R. and Marliana, E. (2019) 'UJI Brine Shrimp Lethality Test (BSLT) Umbi Bawang Tiwai (Eleutherine bulbosa (Mill.) Urb) Dan Uji Toksisitas Akut Fraksi Aktif', Jurnal Riset Kefarmasian Indonesia, 1(1), pp. 1-10. doi: 10.33759/jrki.v1i1.43.

Maharani, T., Sukandar, D. and Hermanto, S. (2016) 'Karakterisasi Senyawa Hasil Isolasi dari Ekstrak Etil Asetat Daun Namnam (Cynometra Cauliflora L.) yang Memiliki Aktivitas Antibakteri', Jurnal Kimia VALENSI, 2(1), pp. 55-62. doi: 10.15408/jkv.v2i1.3084.

Manongko, P. S., Sangi, M. S. and Momuat, L. I. (2020) 'Uji Senyawa Fitokimia dan Aktivitas Antioksidan Tanaman Patah Tulang (Euphorbia tirucalli L.)', Jurnal MIPA, 9(2), p. 64. doi: 10.35799/jmuo.9.2.2020.28725.

Mshelia E.H., W. E. M., , Maigari, A. U. and , Yohanna Christopher., and Ismail, F. (2016) 'Cytotoxicity And Antioxidant Activity Of Stem Bark Extracts of A zanza garckeana (kola of Tula)', 3(2).

Mulia, K., Endang Zainal Hasan, A. and Suryani (2016) 'Current Biochemistry CURRENT BIOCHEMISTRY Total Phenolic, Anticancer and Antioxidant Activity of Ethanol Extract of Piper retrofractum Vahl from Pamekasan and Karang Asem', Jl. Agatis Gd. Fapet Lt, 3(2), pp. 80-90. Available at: http://biokimia.ipb.ac.id.

Mutiah, R. (2017) 'Studi Efikasi Dan Keamanan Ekstrak Akar Dan Daun Calotropis Gigantea Terhadap Sel Kanker Kolon Dan Sel Kanker Payudara Secara In Vitro', Journal of Islamic Medicine, 1(2), pp. 67-75. doi: https://doi.org/10.18860/jim.v1i2.445 5.

Nofita, N., Maria Ulfa, A. and Delima, M. (2021) 'Uji Toksisitas Ekstrak Etanol Daun Jambu Biji Australia (Psidium Guajava L) Dengan Metode BSLT (Brine 
Shrimp Lethality Test)', JFL: Jurnal Farmasi Lampung, 9(1), pp. 10-17. doi: 10.37090/jfl.v9i1.326.

Society, A. cancer (2020) American cancer society. Available at: https://www.cancer.org/treatment/tre atments-and-side-effects/treatmenttypes/radiation/effects-on-differentparts-of-body.html (Accessed: 28 December 2020).

Sumarlin, L. O. et al. (2018) 'Evaluasi In Vitro Kemampuan Penyerapan Glukosa oleh Ekstrak Daun Namnam (Cynometra cauliflora) pada Otot Diafragma Tikus', Jurnal Kimia VALENSI, 4(1), pp. 67-74. doi: 10.15408/jkv.v4i1.7345.

Suraduhita, A. (2017) SITOTOKSISITAS EKSTRAK ETANOL DAUN TAPAK DARA (Catharanthus roseus (L.) G. Don.) TERHADAP CELL LINE KANKER SERVIKS (hela) DAN CELL LINE KANKER PAYUDARA (MCF-7). Universitas Atma Jaya Yogyakarta. doi: http://ejournal.uajy.ac.id/id/eprint/11903.

Tatiana, W. S. and Ria, S. (2020) 'Uji aktivitas antioksidan dengan metode dpph dan uji sitotoksik terhadap sel kanker payudara t47d pada ekstrak daun kemangi', Jurnal Farmasetis, 9(1), pp. 51-64.

Yudistira, A. (2017) 'Cytotoxic Activity Test of Sesewanua Leaves Extract ( Clerodendron squmatum Vahl .) to Breast Cancer T47D Cell', Pharmacon, 6(2), pp. 45-51. Available at: https://ejournal.unsrat.ac.id/index.php /pharmacon/article/view/16420. 